\title{
THE INFLUENCE SERVICES QUALITY, PROMOTION AND PHYSICAL EVIDENCE AGAINST CUSTOMER LOYALTY CV. FUNTASTIC TOUR AND TRAVEL
}

\author{
SATRIA AJI GUMELAR \\ SAPARUDDIN M \\ Email : saparuddin@feunj.ac.id, phone : 081318811577, \\ web www.edunomic.net
}

\begin{abstract}
The purpose of this study is to find the influence of quality services, promotion and physical evidence of customer loyalty on CV. Funtastic Tour and Travel.

Analysis method of research used quantitative analysis to compute multiple linear regressions by using the Statistical Program for Social Science (SPSS) 20 conducted on customers CV. Funtastic Tour and Travel.

The results of this study indicated that the independent variable (quality of services, promotion and physical evidence were able to explain the variations that occurred on customer loyalty by $60,2 \%$. And explained that the variable of quality service did not affect the customer loyalty with a regression coefficient 0,114 , while the promotion variable affected positively to the customer loyalty with regression coefficients 0,274 and most dominant variable influenced positively customer loyalty is variable physical evidence of regression coefficients 0,588 .
\end{abstract}

Key word: service quality, promotion, physical evidence and customer loyalty

\section{INTRODUCTION}

The progress of transportation on this era of globalization, making the distance, limit, time between regions is not a major obstacle. Because of the existence of transport made distance and boundaries between regions are getting closer and the mileage time is getting short. 
Transportation holds an important role because facilitates community in reaching a place for a particular purpose. With business prospects or the interests not only in one place or one specific area but transportation is very important for an individual or group to support their journey. Therefore the demand of services travel is growing up rapidly. A level of human mobility from one place to another is increasing year by year. The purpose of consumers demands are departments, tour travel, travel pilgrimage or other interests. This will affect the transportation facility, services package and travel. On competition of travel service agency there were many tour and travel agencies provide services together with an instance provider of transportation, tourism place or tourist agent until lodging such as hotels, hostels, and motel and so on.

Quality of service is one of factors that may affect the competitive advantage. Therefore every tour and travel company strives to develop and improve the quality of its services, in order to be able to compete with the quality of service provided by its competitor.

The most important element in service product is quality. Often there are differences about what they meant by quality. From the view of producing the quality interpreted as a technical composition based on the technical specifications of a product and services. Meanwhile, according to the views of customers, the quality of referring to as skill level service products to meet what is expected of the service product customers.

Therefore, good quality service whether or not depends on the ability of service providers to meet customers ' expectations on a consistent basis. From the view of customers, the quality services product is very concerned with customer satisfaction. With satisfied customer of the service product, then the position of service product will be better in competition.

Except the quality of services, promotion is also important in influencing the customer choice to use service products, promotional variable as well as a media product introduction services offered to customers, appropriately and effectively promotion media that offered to the customer became one of the important variables in captivate the interest of customers in using the products and services marketed, because many products services are offered sometimes not apprehended the market because it was less precise and effective promotion was done. In addition, 
physical evidence is one of the crucial factors which affect the success of a service, because of the ease in doing the interaction with the customer is an important key to win the market. The physical evidence is also often determine in winning the customer choice competition and would also have an effect on customer loyalty.

\section{THEORITICAL FRAMWORK Quality Service}

Gefen (2002) argued that the quality of service as subjective comparisons between the qualities of service those consumers received and what had actually. According to sivadas and Prewitt (2000) the quality of service is customer appraisement on the value of the superior or the excellence of product from the value or benefits that the customer received based on a comparison what was given ( customers ) and what was received ( customers ).

\section{Promotion}

Promotion according to sustain and Irawan 2005 substantially is a form of marketing communications and hoped to encourage demand. Meant marketing communications are marketing activity trying to spread information, influence and or remind market target over companies and their products to be willing to receive, buy, and loyal to products or services offered by the companies concerned. Meanwhile, according to Alma (2004: 163) the promotion is a form of marketing communication, which is a marketing activity that trying to diffusing information, influencing/persuading, and remind the market targeton the company and its products in order to be willing to receive, purchase, and loyal to the product offered by the company concerned. Promotion is one of marketing mix elements that cannot be ignored in a sales process. In an effort to support the sales of a product and introduced it to other people or consumers, as well as to attract consumers to buy products then required an effort to promote the product.

\section{Physical Evidence}

Physical evidence is physical environment company created and the place of service providers and consumers interacting, plus tangible elements anything desired to communicate or supporting roles that service. (Lupyoadi, 2001: 77). While according to Bulk (1992) physical evidence is a state or condition in which are also included atmosphere. The characteristics of 
the physical environment are the most visible facet in relation to the situation.This is the situation when the situation and conditions of geography and the environment institutional, decorating, room, sound, smells, light, weather, and layouts that appear or are important environmental as stimuli object.

\section{Customer Loyalty}

According to Ahmad Mardalis (2005) literally means loyalty loyalty, one's loyalty towards an object. According to Basu Swastha Dharmmesta (2005) the term customer loyalty actually comes from the brand loyalty that reflects a particular brand on customer loyalty. Customer loyalty and brand loyalty show the same thing, therefore its use can't be differentiated and can be expressed in. So the customer loyalty is the response was bad manner revealed continuous by the decision maker with respect to one or several alternative brands from a host of similar brands and is a function of psychologicalprocess or decision makers, evaluative. Where did Mowen and Minor in Basu Swastha Dharmmesta (2005) that customer loyalty is a condition in which consumers have a positive attitude towards a brand, the brand has a commitment to, and intend to continue to purchase in the future.

\section{RESEARCH METHODS \\ Scope of Research}

The scope of this Research Study was conducted on a CV. Funtastic Tour and Travel marketing located in Jakarta and Depok. CV. Funtastic Tour and Travel is a company engaged in the service of travel services (tour \& amp; travel) as well as providing services both domestic and international tickets, hotel reservations, vehicle rentals, package, transportation and MICE (Meeting, Incentive, Conference and Exhibition). In doing marketing to consumers, CV. Funtastic Tour and Travel is headquartered in Depok also has two branches in Jakarta (Jakarta East and West), as many as 128 Respondents.

\section{Methodology}

Approximate of this research study used quantitative method, that was collected from questionnaire. Quantitative method used to identify all concepts that had been purpose of research (Malhotra, 2005). This questionnaire used to get some data's description for examining hypothesis and analysis' model. Data's description using closed questionnaire that some draft's question and statement has alternative's answer and respond, 
so respondent has to choose one of the alternative's answer allowed.

\section{Variable's Operational}

Variables are examined in this study there were 3 independent's variables those are quality of services, promotion, and Physical Evidence another dependent's variable is loyalty of customer. Here are the dimensions that are contained in each of these variables, namely:

A. Quality of Service (X1):
1. Reliability
2. Responsiveness
3. Assurance
4. Empathy
5. Tangibles

B. Dimension of Promotion (X2)
1. Advertising
2. Personal Selling
3. Publicity
4. Sales Promotion
5. Direct Marketing

C. Dimency of Physical Evidence (X3)
1. Design Facility
2. Comfortabel
3. Equipment
4. Assurance
5. Uniform

D. Dimency of Loyalty Customer ( $\mathrm{Y}$ )

1. Positive Word Of Mounth

2. Complain Behavior

3. Switching Behavior

4. Willingness To Pay More.

\section{RESULTS AND DISCUSSION Description of Respondent}

Demographic data as well as an overview of the research object will also be presented in this chapter. It is intended able to know the character of the respondent. Researchers obtained research's data with diffuse questionnaire was conducted on July 5, 2013 until August 5, 2013. 


\section{Hypothesis Testing}

\section{T Test}

TabLE 4.1

Value of T Test Coefficients ${ }^{a}$

\begin{tabular}{|c|c|c|c|c|c|}
\hline \multirow[t]{2}{*}{ Model } & \multicolumn{2}{|c|}{$\begin{array}{c}\text { Unstandardized } \\
\text { Coefficients }\end{array}$} & $\begin{array}{c}\text { Standardized } \\
\text { Coefficients }\end{array}$ & \multirow[t]{2}{*}{$\mathrm{T}$} & \multirow[t]{2}{*}{ Sig. } \\
\hline & B & Std. Error & Beta & & \\
\hline (Constant) & -14.954 & 3.164 & & -4.726 & .000 \\
\hline Services Quality & -.114 & .100 & -.153 & -1.141 & 256 \\
\hline Promotion & 274 & .069 & 249 & 3.972 & .000 \\
\hline $\begin{array}{l}\text { Physical } \\
\text { Evidence }\end{array}$ & .588 & .104 & .774 & 5.634 & .000 \\
\hline
\end{tabular}

a. Dependent Variable: Customer Loyalty

Source : primary data were processed

Based on variables tests of quality service, promotion, physical Description : evidence, also customer loyalty are $Y=$ Customer Loyalty can formulated with regression X1 = Quality Service equation's prices as follows:

$\mathrm{X} 2$ = Promotion

$Y=-14.954 \mathrm{~B}-0.114 \mathrm{X} 1+0.274 \mathrm{X} 2$

$\mathrm{X} 3=$

Physical

Evidence $+0.588 \times 3+3164$

\section{F Test}

\section{Table 4.2}

\section{Value of $F$ Test}

ANOVA $^{\mathrm{b}}$

\begin{tabular}{|ll|l|l|l|l|l|}
\hline Model & & Sum of Squares & df & Mean Square & F & Sig. \\
\hline 1 & Regression & 1757.109 & 3 & 585.703 & 64.975 & $.000^{\text {a }}$ \\
& Residual & 1117.766 & 124 & 9.014 & & \\
& Total & 2874.875 & 127 & & & \\
\hline
\end{tabular}

a. Predictors: (Constant), Physcal Evidence,

Promotion, Services Quality

b. Dependent Variable: Customer Loyalty

Source : primery data were processed 
From the value of $F$ test can be calculated 64,975 with the probability degree 0,000 (significant). Because the probability is much smaller than 0.05 , then regression model can be used to predict that: the quality services, promotion and Physical Evidence affected on customer loyalty CV. Funtastic Tour \& Travel by togetherness.

\section{Coefficient Determination}

Table 4.3

Coefficient Determination

Model Summary

\begin{tabular}{|l|l|l|l|l|}
\hline Model & $R$ & $R$ Square & Adjusted R Square & $\begin{array}{l}\text { Std. Error of the } \\
\text { Estimate }\end{array}$ \\
\hline 1 & $.782^{\mathrm{a}}$ & .611 & .602 & 3.00237 \\
\hline
\end{tabular}

a. Predictors: (Constant), X3, X2, X1

Source : primary data were processed

Coefficient determination used in this research is value of "Adjusted R Square" with the number is 0.602 or $60.2 \%$. It shows that the independent's variable (quality of service, promotion and physical evidence) can described occurred variations of customer loyalty is about $60,2 \%$ and the remaining described by another variable that not be a subjects in this study.

\section{CONCLUSION \\ RECOMMENDATION}

AND

\section{Conclusions}

1. The conclusions of the object research, it can be concluded that the description of quality service was applied by CV. Funtastic
Tour \& Travel was relatively well, which in providing it service of customer, that CV. Funtastic Tour \& Travel is considered relatively well by customers, but variable of quality service in this research had no effect in increasing customer loyalty on this CV. , in this case promotional strategy had been significant then the customers can get information about the product and services of CV. Funtastic Tour \& Travel and are interested to use it. CV. Funtastic Tour \& Travel gave a positive impact on customer loyalty. Physical Evidence has an important action in providing a physical environment, facilities and another tangible element 
they are dominant variable in giving a positive influence for increasing customer loyalty.

2. From the results of data, shown that determination coefficient used in this research is "Adjusted R Square" with the number 0.602 or rap $60.2 \%$. It shown that the independent's variable (quality of service, promotion and physical evidence) can explain the occurred variation in customer loyalty is $60,2 \%$ and the remaining percents described by another variable that not be a subjects in this study.

3. They are three dominants factors that influenced customer's loyalty: First is Physical evidence that indicated most influenced customers loyalty with regression coefficient is 0,588 significantly with $0,000<0,05$. Second factor is promotion variable that influenced customers loyalty with regression coefficient is 0,74 . So The Third factor is variable of customer loyalty with regression coefficient is $-0,114$ which apparently did no effect on customer loyalty.

\section{Recommendation}

1. Companies need to pay attention to empathy and tangible dimensions in service quality, especially on indicators of attention to the desires of the customer and the physical facilities such as car parking capacity and the provision of washroom / toilet. So as to improve customer perception that the better the quality of services provided by CV . Funtastic Tour \& Travel.

2. Management CV . Funtastic Tour \& Travel need to pay attention to the dimensions publicity, sales promotion and direct marketing , especially in the print publications on CV services products. Funtastic Tour \& Travel, and gift and souvenir discounts for customers as well as increase the supply CV directly to customers . Funtastic Tour \& Travel in order to increase customer loyalty CV . Funtastic Tour \& Travel.

3. Physical Evidence is the element most influence on customer loyalty in this study, but it should be noted regarding the CV office appearance . Funtastic Tour \& Travel to make it more attractive , and harmonious employee clothing CV . Funtastic Tour \& Travel, so that customer loyalty CV . Funtastic Tour \& Travel can be improved. 


\section{Refference}

Alma, Buchari. 2004. Manajemen Pemasaran dan Pemasaran Jasa, Cetakan Keenam, Bandung : Alfabeta.

Assael, H, 1992. Costumer Behavior \& Marketing Action, Fourth Edition, New York : Kent Publishing Company.

Funtastic Tour and Travel, 2012. Ticketing Table.

Gefen, David. 2002. Customer Satisfaction Barometer, The Swedish Experience, Journal Marketing.

Ghozali, Imam, 2005. Aplikasi Analisis Multivariate dengan Program SPSS, Semarang : Badan Penerbit Universitas Diponogoro.

Ikhan, Muhammad Rafi Dan Dirgantara, Made Bayu, 2011. Pengaruh Kualitas Pelayanan Dan Promosi Penjualan Terhadap Loyalitas Pelanggan Indra Cellular Kudus, Jurnal Ilmiah, Universias Diponogoro.

J. Supranto dan Krisna, Nandan Lima, 2007. Perilaku Konsumen, Jakarta : Mitra Wacana Media.

Kotler, Phillip And Heillier, et al. 2002. Customer Repurchase Intention,
European Journal of Marketing, Vol. 37 No. 11/12, 2003 pp. 1762-1800

Management: Analysis,
Planning, Implementation
and Control, 11th edition,
Prentice Hall International,
Inc., New Jersey
Pemasaran Jilid 1 dan 2,
Jakarta : PT. Indeks
Kelompok Gramedia.
2004. Dasar - Dasar
Pemasaran (Edisi
Kesembilan), Jakarta : PT.
Indeks.

Pemasaran. Jakarta : Erlangga \& Keller, K. L. 2012. Marketing Management 14th Edition. New Jersey : Pearson Education, Inc.

Lovelock, Christopher and Wirtz, Jochan. 2011. Service Marketing : People, Technology, Strategy. Edisi 7. USE : Pearson Education.

Lukman, Andi dan Wuryan, Sophiyanto, 2012. Analisis Kualitas Pelayanan Terhadap Loyalitas Nasabah Bpr Argo Dana Ungaran, Journal Of 
Economics

And

Management Vol. 1.

Lupiyoadi,

Rimbat.

2001.

Manajemen Pemasaran

Jasa. Jakarta : Salemba Empat.

Mardalis, Ahmad. 2005. Meraih Loyalitas Pelanggan, Jakarta : Balai Pustaka.

Noormalasari, Zelika, 2010. Analisis

Bukti Fisik Pada Warnet

Reconnect Dipati Ukur

Bandung Serta Dampaknya

Terhadap Loyalitas

Pelanggan, Jurnal Fakultas

Ekonomi, Universitas

Komputer Indonesia,

Bandung.

Parsetyo, Afik, 2013. Analisis

Pengaruh Harga,

Pelayanan dan Promosi Terhadap Loyalitas

Pelanggan (Studi Kasus

Pada Calcio Stadium Futsal

Kec. Banyumanik Kota

Semarang), Journal IImiah,

Q-man Vol 2 No.7.

Purba, Mas Intan, 2011. Pengaruh

Pelayanan,

Kualitas

Produk, Harga Terhadap

Kepuasan Dan Loyalitas

Konsumen Telekomunikasi

Selular

(Telkomsel)

Prabayar Pada Mahasiswa

Fakultas Matematika Dan

IImu Pengetahuan Alam Universitas

Sumatera
Utara, Tesis Magister Manajemen Universitas Sumatra Utara Medan.

Sangadji, E.M. dan Sopiah. 2010. Metodologi Penelitian (Pendekatan Praktis dalam Penelitian). Yogyakarta: Andi.

Sivadas, Eugene; Baker-Prewitt, Jamie L., 2000. An Examination of The Relationship Between Service Quality, Customer Satisfaction, and Store Loyalty, International Journal of Reyail \& Distribution Management, Vol 28. No 2.

Sulistyo, Joko, 2011. SPSS 17, Cakrawala, Yogyakarta

Swasta, Basu dan Irawan. 2005. Manajemen Pemasaran Modern. Yogyakarta: Liberty.

Thoyib, Armanu dan Suradi, Nanang, 2011. Pengaruh People, Process Dan Physical Evidence Terhadap Loyalitas Melalui Keputusan Mahasiswa Memilih Politeknik Negeri Malang, Jurnal IImiah, Program Pascasarjana Fakultas Ekonomi Universitas Brawijaya.

Tjiptono, Fandy; Chandra, Gregorius, 2005. Service, 
Quality, Satisfaction. Yogyakarta, Indonesia : Andi Yogyakarta

Utomo, Fajar Budi dan Surwardana, Edy, 2012. Analisis Pengaruh Persepsi Pelayanan, Persepsi Harga, Lokasi dan Waktu terhadap Loyalitas Pelanggan dengan Pelanggan
Kepuasan sebagai
Variabel intervening, Journal IImiah, Q-man Vol 1 No.2

Zeithaml, Valarie A., Mary Jo Bitner dan Dwayned D. Gremler, 2006. Services Marketing. Integrating Customer Focus Across the Firm. 4th International Edition. Singapore: McGraw-Hill. 